\title{
CD5 wt Allele
}

National Cancer Institute

\section{Source}

National Cancer Institute. CD5 wt Allele. NCI Thesaurus. Code C73122.

Human CD5 wild-type allele is located in the vicinity of $11 \mathrm{q} 13$ and is approximately $25 \mathrm{~kb}$ in length. This allele, which encodes T-cell surface glycoprotein CD5 protein, may play a role in the modulation of $\mathrm{T}$-cell proliferation. 